\title{
Eksplorasi Potensi Pasir Besi di Pesisir Barat Kecamatan Nusawungu Kabupaten Cilacap berdasarkan Data Resistivitas Batuan Bawah Permukaan
}

\author{
Sukmaji Anom Raharjo dan Sehah* \\ Program Studi Fisika, Fakultas Matematika dan Ilmu Pengetahuan Alam, \\ Universitas Jenderal Soedirman, Jalan Dr. Suparno No. 61 Purwokerto, Banyumas 53122
}

\begin{abstract}
Intisari
Eksplorasi geofisika untuk mengestimasi potensi pasir besi di kawasan pesisir barat Kecamatan Nusawungu, Kabupaten Cilacap telah dilakukan pada bulan Mei-Juli 2017 menggunakan metode resistivitas. Pengukuran data resistivitas dilakukan di 6 titik lokasi yang diperkirakan prospek mengandung bijih besi berdasarkan peta anomali magnetik lokal daerah penelitian. Survey geolistrik resistivitas bertujuan untuk memperkirakan kedalaman dan ketebalan endapan pasir besi dan potensinya. Hasil pemodelan dan interpretasi data resistivitas menunjukkan keberadaan lapisan batuan yang diperkirakan sebagai endapan pasir besi yang berselingan dengan lanau dan lempung dari formasi alluvium di seluruh titik lokasi. Endapan pasir besi terdapat pada kedalaman berkisar 2,39-27,81 meter dengan nilai resistivitas 12,24-46,96 $\Omega \mathrm{m}$. Dengan demikian eksplorasi metode resistivitas ini menunjukkan bahwa potensi pasir besi di daerah penelitian diperkirakan cukup besar.
\end{abstract}

\begin{abstract}
Geophysical exploration to estimate the potency of iron sand in the western coastal area of Sub-district of Nusawungu, Regency Cilacap has been done in May-July 2017 using the resistivity method. Measurements of resistivity data were performed at six points of locations estimated to contain iron ore prospectly based on the local magnetic anomaly map of research area. The geo-electric resistivity survey aims to estimate the depth and thickness of iron sand deposits and their potential. The results of modeling and interpretation of resistivity data show the presence of rock deposit that be estimated as iron sand that coexists alternately with silt and clay from the alluvium formation at all points of locations. The iron sand deposits is at depths of 2.39-25.25 meter with resistivity values of $12.24-46.96 \Omega \mathrm{m}$. Therefore the resistivity method exploration, shows that the potency of iron sand in the research area is estimated to be quite large.
\end{abstract}

KATA KUNCI: geophysical exploration, resistivity data, iron sand, western coastal of Nusawungu.

http://dx.doi.org/10.12962/j24604682.v14i3.3867

\section{PENDAHULUAN}

Salah satu bahan tambang yang bernilai ekonomis yang cukup banyak ditemukan di pesisir Kabupaten Cilacap adalah pasir besi. Eksplorasi terhadap endapan pasir besi ini telah dilakukan pada tahun 1960-1972 dan berhasil mengidentifikasi cadangan pasir besi sebanyak 2.655.236 ton di area seluas 3.090,43 hektar [1]. Kegiatan penambangan di area ini telah menghasilkan kira-kira 300.000 ton konsentrat bijih besi setiap tahun selama tahun 1971-1978 [1]. Kegiatan penambangan yang dilakukan selama bertahuntahun ini telah mengakibatkan cadangan pasir besi mengalami penurunan drastis dan terjadi berbagai dampak negatif, sehingga penambangan berskala besar secara resmi telah ditutup pada tanggal 1 Oktober 2003 [2]. Berdasarkan informasi dari Dinas Pertambangan dan Energi Kabupaten Cilacap pada tahun 2007, estimasi jumlah pasir besi yang

*E-MAIL: sehah.geophysics@gmail.com tersisa tidak lebih dari 600 ribu ton dengan kandungan besi $(\mathrm{Fe})$ kurang dari 52\% sehingga kurang ekonomis [3]. Meskipun kegiatan penambangan dalam skala besar telah ditutup, kegiatan penambangan dalam skala kecil masih terus berjalan hingga saat ini.

Salah satu kawasan di pesisir Kabupaten Cilacap yang diestimasi memiliki potensi pasir besi adalah Pesisir Barat Nusawungu, yang berlokasi sekitar 40 kilometer dari arah timur Kota Cilacap. Cadangan pasir besi di pesisir ini termasuk dalam kawasan yang belum ditambang dengan luas total lebih dari 500 hektar, dengan derajat kemagnetan $12.20 \%$ dan kandungan besi di atas 53\%. Cadangan pasir besi di kawasan ini tersebar dari pesisir Desa Welahan Wetan Kecamatan Binangun hingga Desa Jetis Kecamatan Nusawungu dengan estimasi total kurang lebih $744.678,85$ ton [2]. Penelitian potensi pasir besi di sebelah barat kawasan ini sudah pernah dilakukan, yaitu di pesisir Kecamatan Binangun menggunakan metode magnetik $[4,5]$. Berdasarkan hasil penelitian diperoleh peta anomali magnetik lokal yang menunjukkan adanya sebaran pasir besi di kawasan tersebut secara kualitatif. Sedangkan berdasarkan hasil pemodelan terhadap data 


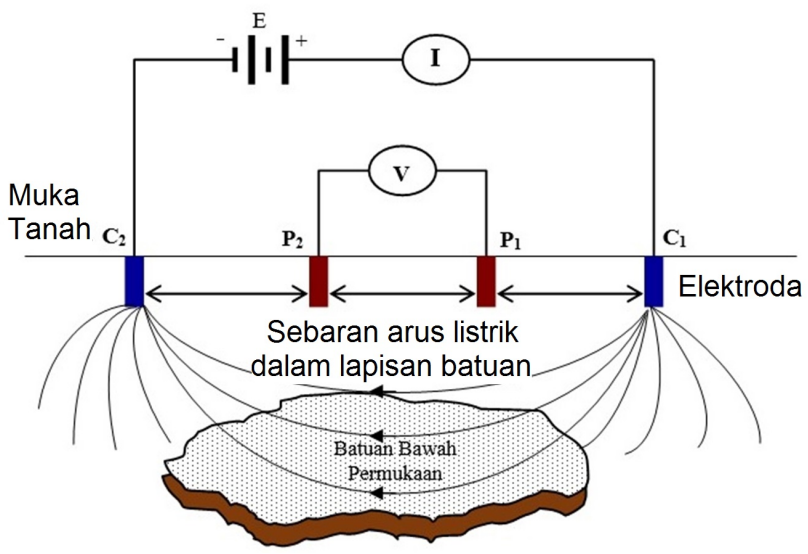

Gambar 1: Skema akuisisi data geolistrik resistivitas menggunakan konfigurasi Schlumberger.

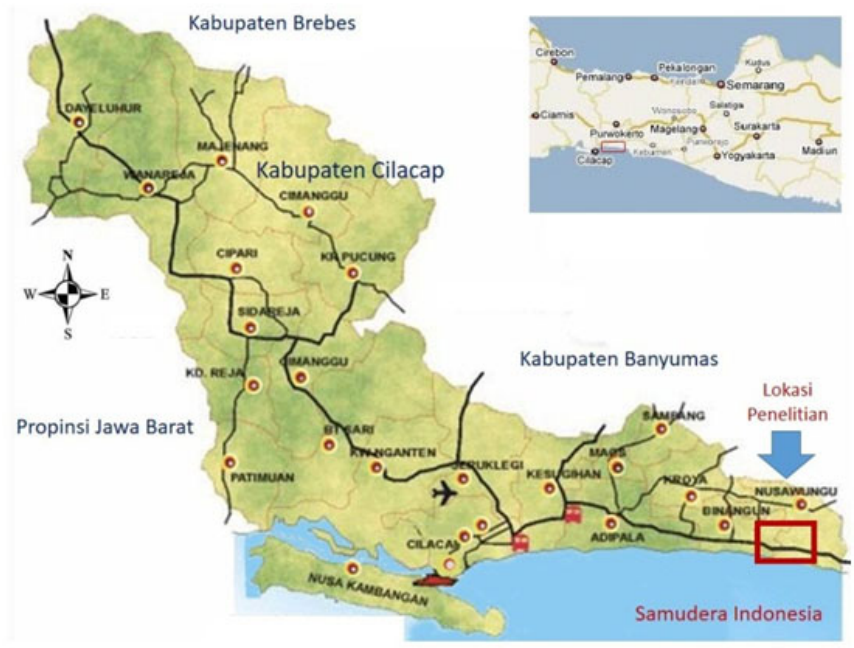

Gambar 2: Lokasi survey geolistrik di pesisir barat Kecamatan Nusawungu Kabupaten Cilacap.

anomali magnetik lokal diperoleh lapisan pasir besi yang berselingan dengan lanau, lempung, pasir, dan kerikil dalam formasi alluvium [5].

Untuk menginvestigasi potensi pasir besi di area pesisir barat Kecamatan Nusawungu, perlu dilakukan survey geofisika. Survey geofisika merupakan pengukuran besaran fisika di permukaan bumi yang digunakan untuk mengidentifikasi model struktur geologi, batuan, dan fenomena fisika lainnya di bawah permukaan. Metode yang diterapkan pada penelitian ini adalah metode resistivitas. Metode resistivitas merupakan metode survey geofisika yang ditujukan untuk merekonstruksi model struktur geologi bawah permukaan atau mengeksplorasi batuan bawah permukaan bumi berdasarkan distribusi nilai tahanan jenis atau resistivitas batuan [6]. Metode resistivitas sangat cocok digunakan untuk mendeteksi adanya nonhomogenitas lapisan batuan bawah permukaan [7]. Metode ini cukup baik untuk eksplorasi dangkal seperti pasir besi [8]. Jika target eksplorasi sangat dalam, informasi yang diperoleh menjadi tidak akurat akibat melemahnya arus listrik untuk
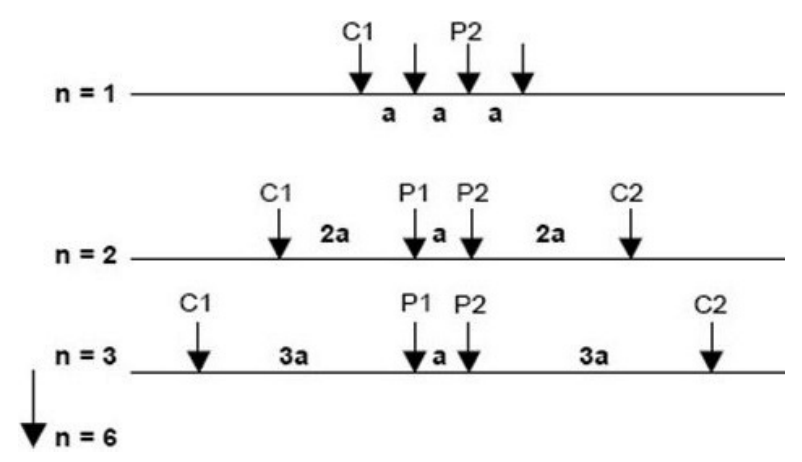

Gambar 3: Pergerakan elektroda arus dalam survey geolistrik resistivitas menggunakan konfigurasi Schlumberger.

jarak bentangan elektroda yang semakin besar.

Teknik akuisisi data survey geolistrik resistivitas dilakukan dengan mengalirkan arus listrik searah (DC) ke dalam lapisan batuan di dalam kerak bumi melalui dua buah elektroda arus; C1 dan C2. Arus listrik yang diinjeksikan ini akan menyebar secara merata ke seluruh medium batuan seperti ditunjukkan pada Gambar 1. Polarisasi listrik yang terjadi di dalam medium batuan diukur nilai beda potensialnya melalui dua buah elektroda potensial, yaitu P1 dan P2. Setelah nilai kuat arus dan beda potensial diperoleh, nilai resistivitas semu (apparent resistivity) batuan bawah permukaan dapat dihitung menggunakan persamaan:

$$
\rho_{a}=K \frac{\Delta V}{I}
$$

dengan $\rho_{a}$ adalah resistivitas semu, $\mathrm{K}$ adalah faktor geometri, $\Delta \mathrm{V}$ adalah beda potensial, dan I adalah kuat arus. Nilai faktor geometri (K) tergantung dari model konfigurasi elektroda yang digunakan [7]. Pada penelitian ini digunakan konfigurasi Schlumberger karena target eksplorasi yang diinginkan adalah informasi lapisan batuan secara vertikal (vertical sounding). Untuk konfigurasi Schlumberger, susunan dan jarak bentangan antar elektroda didesain sebagaimana Gambar 1, dengan nilai faktor geometrinya dapat dinyatakan dengan persamaan:

$$
\begin{aligned}
K_{S c h} & =\frac{2 \pi}{\left(\frac{1}{C_{1} P_{1}}-\frac{1}{P_{1} C_{2}}\right)-\left(\frac{1}{C_{1} P_{2}}-\frac{1}{P_{2} C_{2}}\right)} \\
& =\pi\left(\frac{a^{2}-b^{2}}{2 b}\right)
\end{aligned}
$$

dengan a adalah $\frac{C_{1} C_{2}}{2}$ dan b adalah $\frac{P_{1} P_{2}}{2}$ [7].

\section{METODE PENELITIAN}

Akuisisi data survey geolistrik resistivitas dilakukan pada bulan Mei-Juli 2017 di kawasan pesisir Barat Kecamatan Nusawungu Kabupaten Cilacap seperti terlihat pada Gambar 2. Pengolahan, pemodelan, dan interpretasi data dilakukan di Laboratorium Elektronika Instrumentasi dan Geofisika, Fakultas MIPA, UNSOED Purwokerto. Peralatan yang 


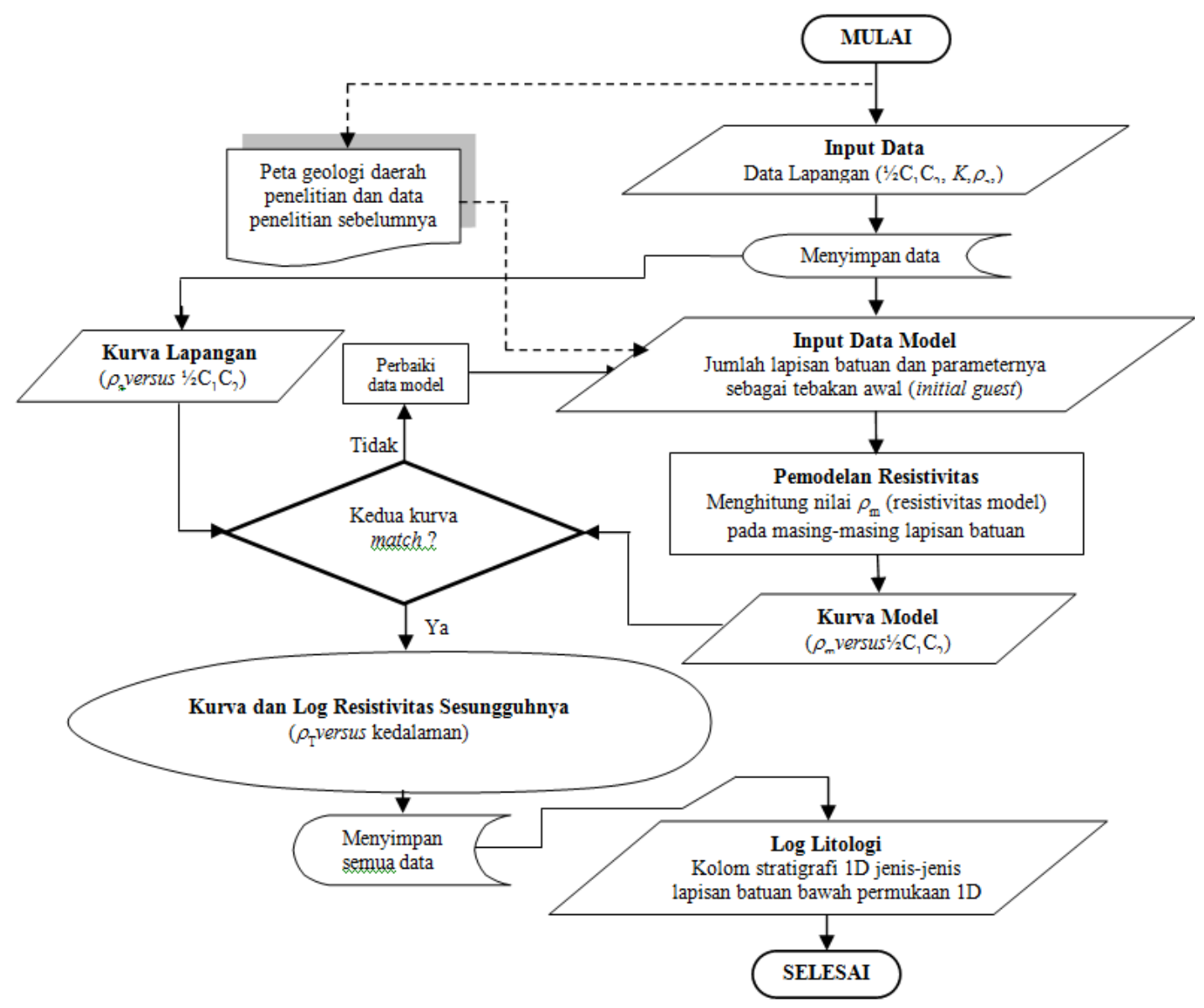

Gambar 4: Diagram alir pengolahan, pemodelan, dan interpretasi data resistivitas menggunakan perangkat lunak Progress 3.0 yang diterapkan dalam penelitian ini.

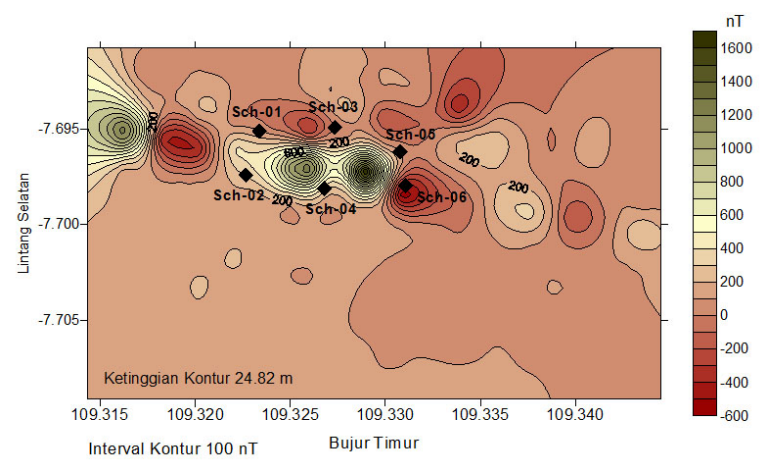

Gambar 5: Ploting titik-titik sounding di atas peta kontur anomali magnetik lokal dalam survey geolistrik resistivitas.

digunakan dalam survey geolistrik resistivitas adalah Resistivitymeter tipe Naniura NRD-22S lengkap dengan kabel, elektroda, catu daya, rol meter, palu, perangkat lunak, dan beberapa komponen pendukung seperti Global Positioning System (GPS), peta geologi, dan kompas. Data yang diperoleh dari akuisisi di lapangan adalah sekumpulan data (array) yang terdiri atas kuat arus (I), beda potensial (V), dan jarak bentangan antar elektroda untuk masing-masing lintasan pengukuran. Selanjutnya nilai resistivitas semu $\left(\rho_{a}\right)$ lapisan-lapisan batuan bawah permukaan dihitung sebagaimana Pers.(1).

Penelitian ini diawali dengan survey magnetik hingga diperoleh peta kontur anomali magnetik lokal yang secara kualitatif menggambarkan pola sebaran endapan pasir besi di daerah penelitian [9]. Berdasarkan peta anomali magnetik lokal, maka dilakukan pengeplotan titik-titik sounding pada peta kontur tersebut untuk keperluan akuisisi data resistivitas. Akuisisi data resistivitas pada titik-titik sounding dilakukan di atas zona yang diperkirakan prospek mengandung pasir besi berdasarkan pola sebaran anomali magnetik lokal dan informasi geologi setempat. Akuisisi data resistivitas dilakukan secara satu dimensi (1D) menggunakan konfigurasi Schlumberger. Artinya data resistivitas yang diperoleh hanya menunjukkan informasi lapisan-lapisan batuan bawah permukaan secara vertikal ke bawah atau disebut sebagai teknik Vertical Electrical Sounding (VES) [10].

Teknik akuisisi data resistivitas menggunakan konfigurasi Schlumberger dilakukan dengan cara memvariasi jarak elektroda $\mathrm{C}_{1}$ dan $\mathrm{C}_{2}$ terhadap $\mathrm{P}_{1}$ dan $\mathrm{P}_{2}$ seperti Gambar 1. Setiap variasi jarak, dilakukan pengukuran kuat arus, beda potensial, serta setengah jarak bentangan elektroda $C_{1}$ dan $C_{2}$. Variasi 

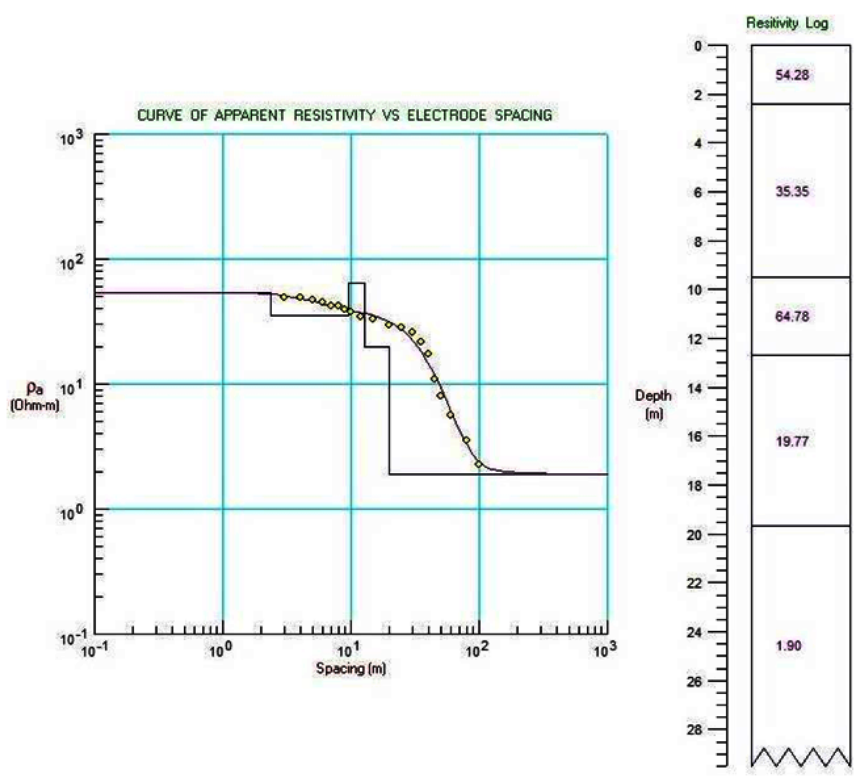

Gambar 6: Hasil pemodelan resistivitas batuan bawah permukaan di titik Sch-01.

jarak ini dilakukan untuk memperoleh informasi model struktur dan kedalaman batuan bawah permukaan berdasarkan nilai resistivitas batuan secara vertikal 1D. Adanya perbedaan resistivitas batuan bawah permukaan, dapat terlihat secara jelas ketika penentuan kedalaman lapisan batuan yang memiliki nilai resistivitas berbeda-beda. Jarak bentangan elektroda potensial $\left(\mathrm{P}_{1}\right.$ dan $\left.\mathrm{P}_{2}\right)$ dapat diubah secara perlahan, sedangkan elektroda arus $\left(\mathrm{C}_{1}\right.$ dan $\left.\mathrm{C}_{2}\right)$ selalu digerakkan secara gradual menjauhi titik sounding sesuai penambahan jarak bentangan elektroda, seperti dapat dilihat pada Gambar 3. Semakin lebar jarak bentangan elektroda, informasi batuan bawah permukaan yang diperoleh juga semakin dalam [11].

Nilai resistivitas semu (apparent resistivity) bukan nilai resistivitas yang sesungguhnya. Nilai resistivitas semu tergantung dari jarak elektroda, heterogenitas medium batuan, dan sifat fisika seperti kandungan logam, air, suhu, komposisi mineral, tekstur, permeabilitas, dan umur geologi [7]. Data hasil akuisisi, selanjutnya diolah sehingga diperoleh kurva resistivitas semu $\left(\rho_{a}\right)$ versus jarak bentangan elektroda arus $\left(\frac{C_{1} C_{2}}{2}\right)$. Kurva resistivitas semu ini digunakan sebagai dasar menghitung nilai resistivitas sesungguhnya untuk setiap lapisan batuan bawah permukaan melalui suatu pemodelan. Hasil pemodelan yang diperoleh adalah kurva resistivitas sesungguhnya versus jarak $\frac{C_{1} C_{2}}{2}$; serta $\log$ resistivitas batuan bawah permukaan versus kedalaman. Interpretasi dilakukan terhadap log resistivitas sehingga diperoleh log litologi yang menggambarkan berbagai jenis lapisan batuan bawah permukaan lengkap dengan nilai resistivitas, kedalaman, dan formasinya. Sistematika pengolahan data secara lengkap dapat dilihat pada diagram alir seperti Gambar 4.
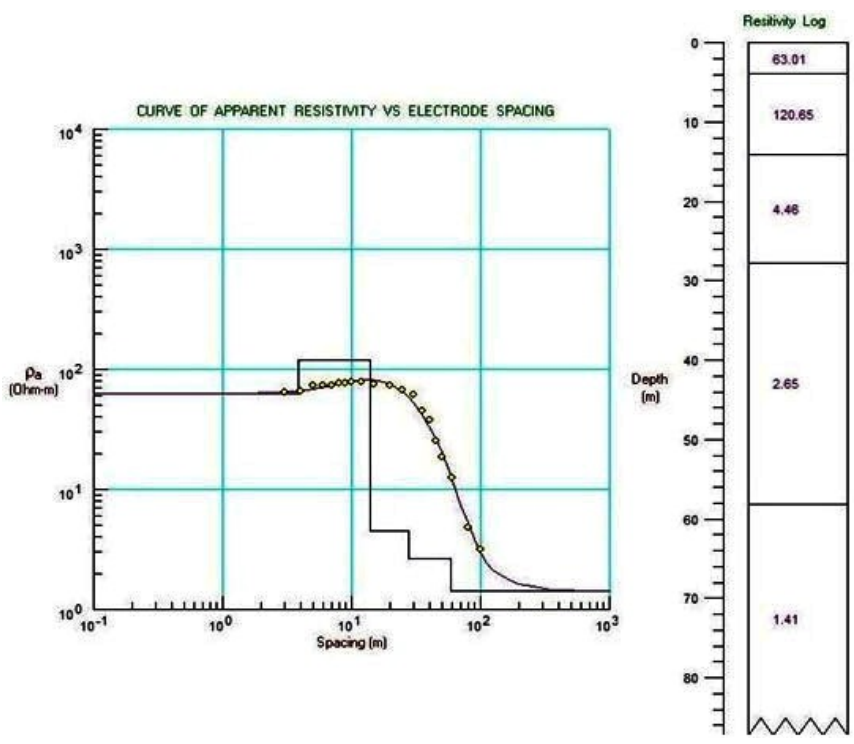

Gambar 7: Hasil pemodelan resistivitas batuan bawah permukaan di titik Sch-02.

TABEL I: Hasil interpretasi litologi batuan bawah permukaan pada titik Sch-01 (Posisi titik sounding 109,2718 ${ }^{\circ}$ BT dan 7,6873 ${ }^{\circ}$ LS).

\begin{tabular}{lccl}
\hline $\begin{array}{l}\text { Lapisan } \\
\text { Batuan }\end{array}$ & $\begin{array}{l}\text { Resistivi- } \\
\text { tas }(\Omega \mathrm{m})\end{array}$ & $\begin{array}{c}\text { Kedalam- } \\
\text { an (meter) }\end{array}$ & $\begin{array}{l}\text { Interpretasi } \\
\text { Litologi }\end{array}$ \\
\hline Lapisan 1 & 54,28 & $0-2,39$ & $\begin{array}{l}\text { Tanah permukaan (top soil) } \\
\text { berselingan dengan pasir besi }\end{array}$ \\
Lapisan 2 & 35,35 & $2,39-9,47$ & $\begin{array}{l}\text { Pasir besi berselingan dengan } \\
\text { lanau dan lempung }\end{array}$ \\
Lapisan 3 & 64,78 & $9,47-12,69$ & $\begin{array}{l}\text { Pasir besi berselingan dengan } \\
\text { lanau, lempung, dan kerikil }\end{array}$ \\
Lapisan 4 & 19,77 & $\begin{array}{c}12,69-19,67 \\
\text { Pasir lempungan }\end{array}$ \\
Lapisan 5 & 1,90 & $>19,67$ & Pasir (terintrusi air laut) \\
\hline \hline
\end{tabular}

\section{HASIL DAN PEMBAHASAN}

Lokasi titik-titik sounding pada akuisisi data resistivitas didasarkan atas peta kontur anomali magnetik lokal yang telah diperoleh pada survey sebelumnya [9], sebagaimana Gambar 5. Peta kontur anomali magnetik lokal menunjukkan

TABEL II: Hasil interpretasi litologi batuan bawah permukaan pada titik Sch-02. (Posisi titik sounding 109,2718 ${ }^{\circ}$ BT dan 7,6873 ${ }^{\circ}$ LS)

\begin{tabular}{|c|c|c|c|}
\hline $\begin{array}{l}\text { Lapisan } \\
\text { Batuan }\end{array}$ & $\begin{array}{l}\text { Resistivi- } \\
\operatorname{tas}(\Omega \mathrm{m})\end{array}$ & $\begin{array}{l}\text { Kedalam- } \\
\text { an (meter) }\end{array}$ & $\begin{array}{l}\text { Interpretasi } \\
\text { Litologi }\end{array}$ \\
\hline Lapisan 1 & 63,01 & $0-3,89$ & $\begin{array}{l}\text { Tanah permukaan (top soil) } \\
\text { berselingan dengan pasir besi }\end{array}$ \\
\hline Lapisan 2 & 120,65 & $3,89-14,08$ & $\begin{array}{l}\text { Pasir, lempung, kerikil, dan } \\
\text { kerakal }\end{array}$ \\
\hline Lapisan 3 & 4,46 & $14,08-27,81$ & Pasir lempungan \\
\hline Lapisan 4 & 2,65 & $27,81-58,16$ & Pasir (terintrusi air laut) \\
\hline Lapisan 5 & 1,41 & $>58,16$ & \\
\hline
\end{tabular}




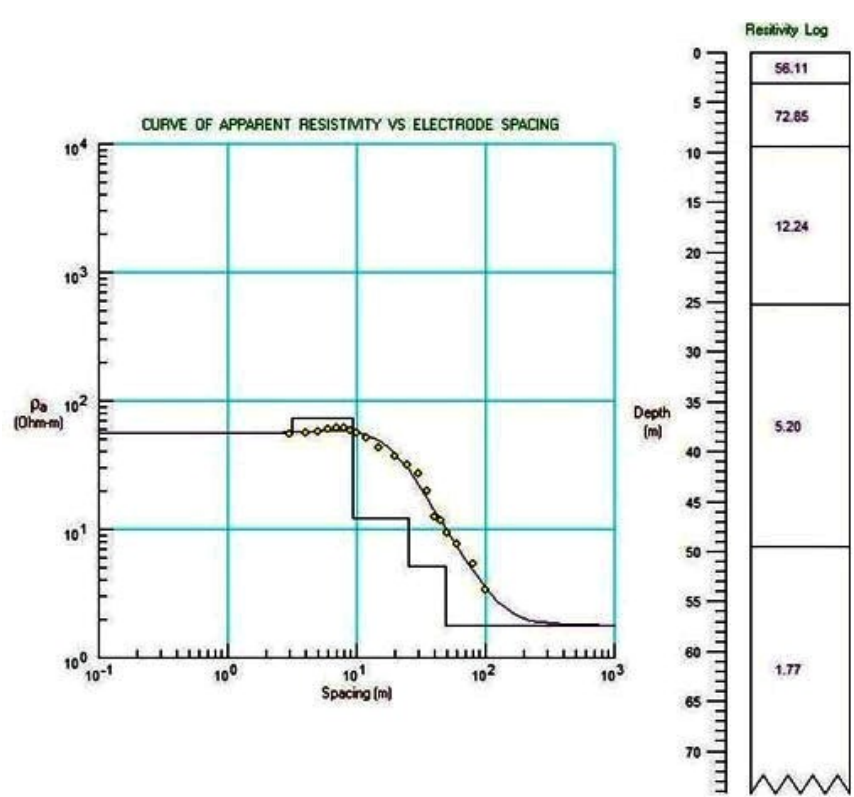

Gambar 8: Hasil pemodelan resistivitas batuan bawah permukaan di titik Sch-03.
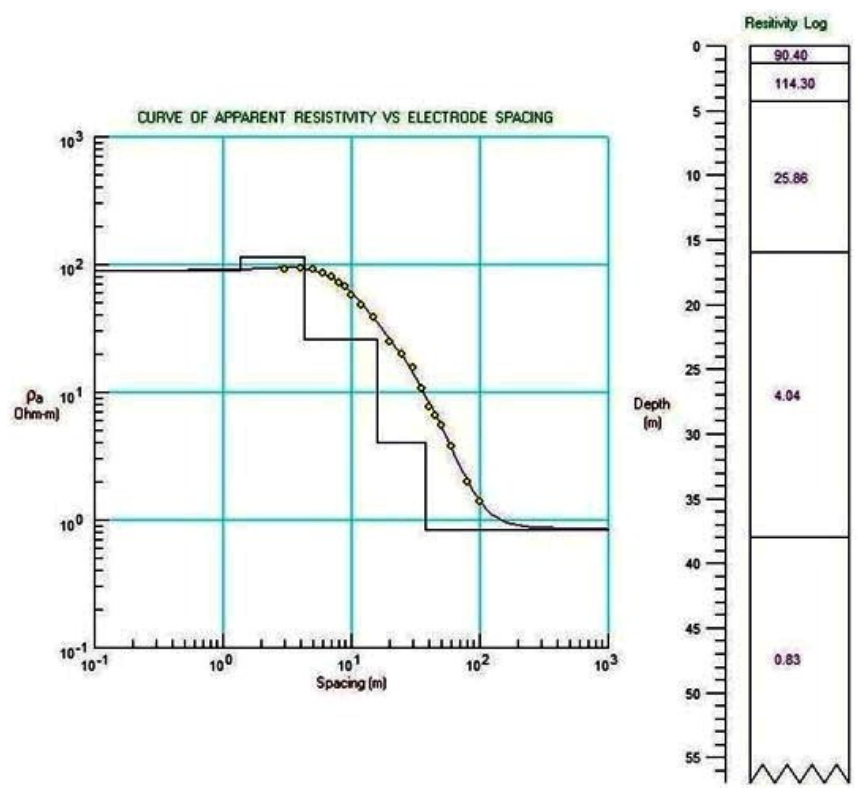

Gambar 9: Hasil pemodelan resistivitas batuan bawah permukaan di titik Sch-04.

bahwa trend anomali magnetik (dalam bentuk dipole magnetik) terletak relatif di bagian tengah. Kawasan ini diinterpretasi terdapat sebaran pasir yang mengandung butiran bijih besi yang berasal dari formasi alluvium pantai [9]. Hasil interpretasi tersebut sesuai dengan peta geologi daerah penelitian yang menyatakan bahwa formasi alluvium pantai tersusun atas pasir terpilah baik hingga sedang dan sangat lepas yang mengandung butiran bijih besi $[12,13]$. Secara keseluruhan daerah penelitian terletak di kawasan pesisir yang tertutup formasi alluvium, termasuk alluvium pantai [13].
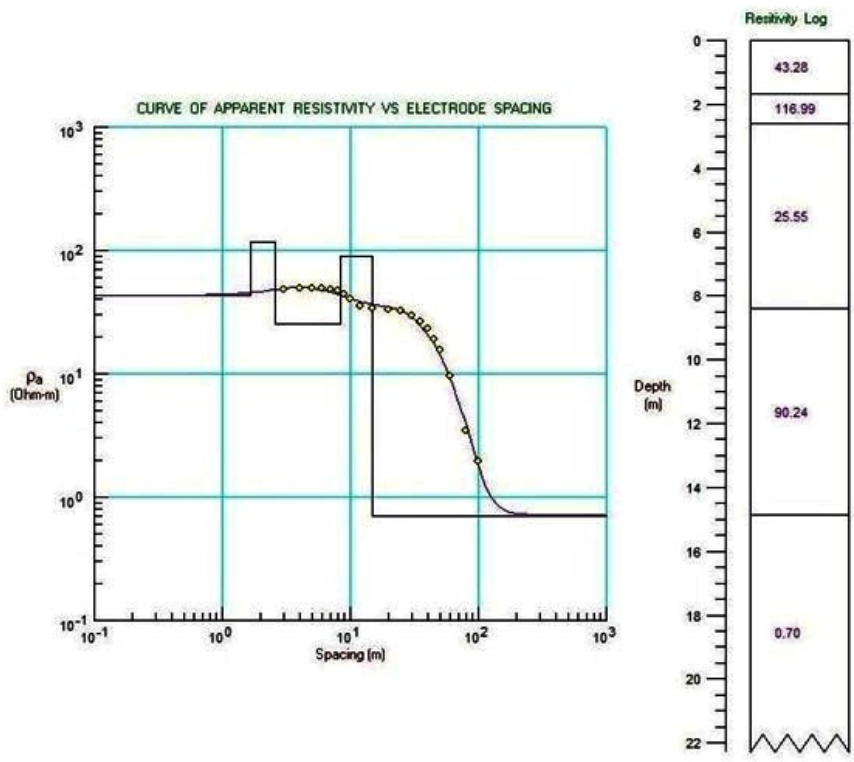

Gambar 10: Hasil pemodelan resistivitas batuan bawah permukaan di titik Sch-05.
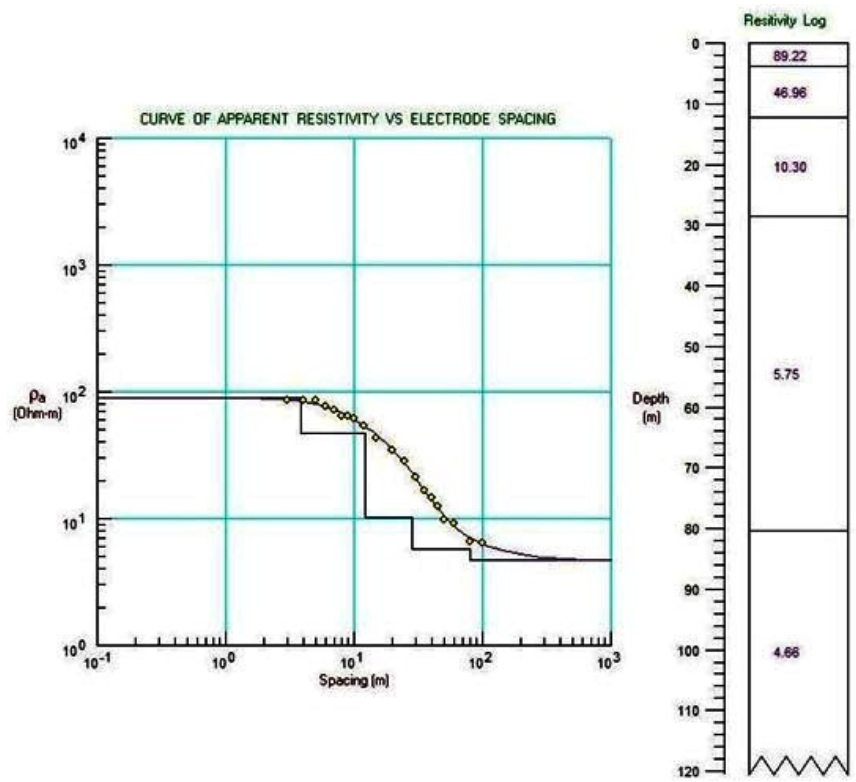

Gambar 11: Hasil pemodelan resistivitas batuan bawah permukaan di titik Sch-06.

Jumlah titik sounding untuk survey resistivitas yang diletakkan di kawasan tersebut adalah enam titik. Setelah diperoleh nilai kuat arus dan beda potensial pada akuisisi data, nilai resistivitas semu masing-masing lapisan pada setiap titik sounding dapat dihitung. Hasil perhitungan digunakan sebagai dasar pemodelan sehingga diperoleh nilai resistivitas sesungguhnya $\left(\rho_{T}\right)$ untuk setiap lapisan batuan bawah permukaan, sebagaimana terlihat pada Gambar 6 hingga Gambar 11 .

Gambar 6 merupakan hasil pemodelan nilai resistivitas batuan bawah permukaan pada titik Sch-01 berupa kurva 


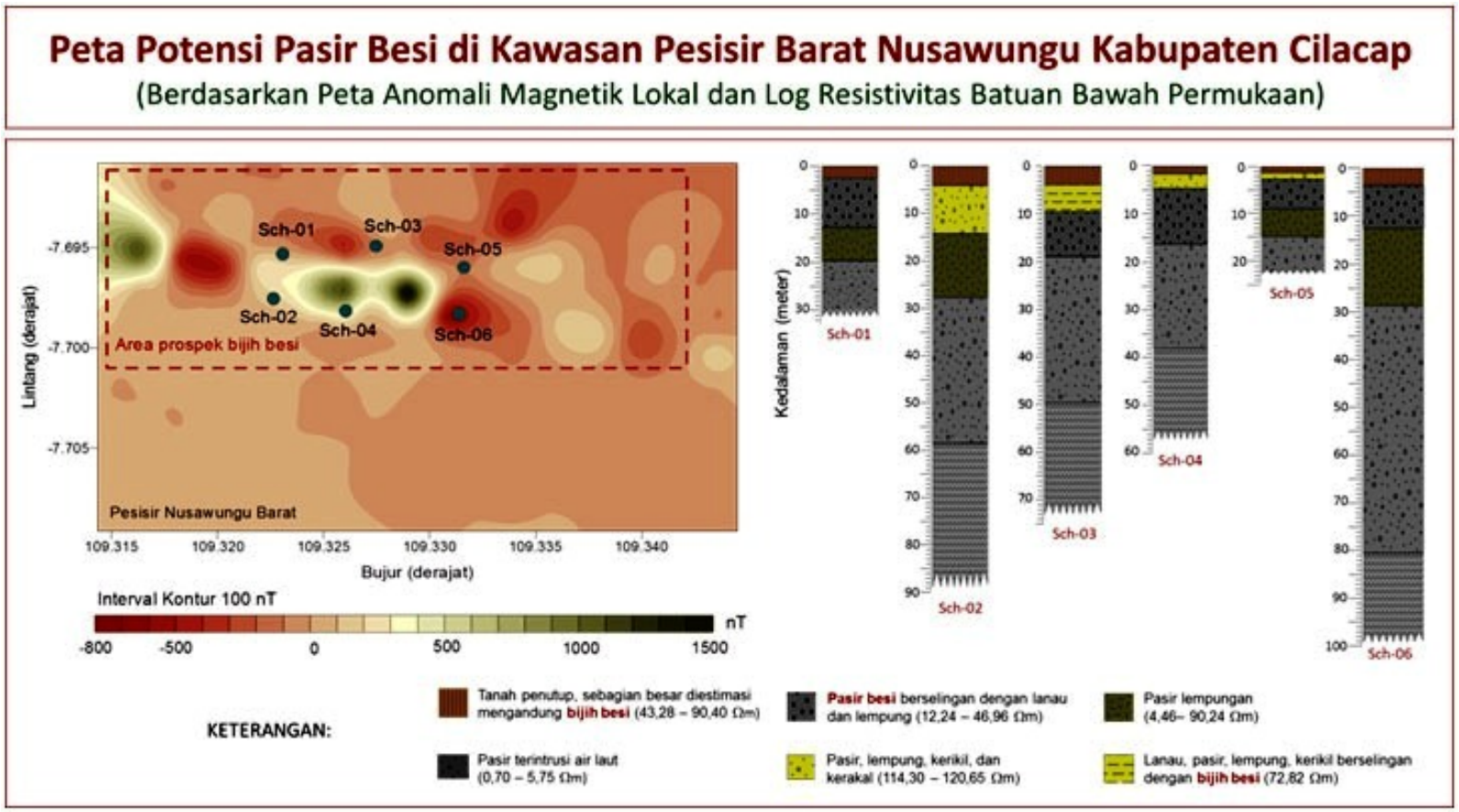

Gambar 12: Peta potensi pasir besi di kawasan pesisir barat Kecamatan Nusawungu Kabupaten Cilacap berdasarkan peta anomali magnetik lokal dan resistivitas batuan.

TABEL III: Hasil interpretasi litologi batuan bawah permukaan pada titik Sch-03. (Posisi titik sounding $109,2718^{\circ}$ BT dan 7,6873 ${ }^{\circ}$ LS)

\begin{tabular}{|c|c|c|c|}
\hline $\begin{array}{l}\text { Lapisan } \\
\text { Batuan }\end{array}$ & $\begin{array}{l}\text { Resistivi- } \\
\operatorname{tas}(\Omega \mathrm{m})\end{array}$ & $\begin{array}{l}\text { Kedalam- } \\
\text { an (meter) }\end{array}$ & $\begin{array}{l}\text { Interpretasi } \\
\text { Litologi }\end{array}$ \\
\hline Lapisan 1 & 56,11 & $0-3,13$ & $\begin{array}{l}\text { Tanah permukaan (top soil) } \\
\text { berselingan dengan pasir besi }\end{array}$ \\
\hline Lapisan 2 & 72,82 & $3,13-9,46$ & $\begin{array}{l}\text { Pasir, lempung, kerikil, dan kera- } \\
\text { kal berselingan dengan bijih besi }\end{array}$ \\
\hline Lapisan 3 & 12,24 & $9,46-25,25$ & $\begin{array}{l}\text { Pasir besi berselingan dengan } \\
\text { lanau dan lempung }\end{array}$ \\
\hline Lapisan 4 & 5,20 & $25,25-49,51$ & Pasir lempungan \\
\hline Lapisan 5 & 1,77 & $>49,51$ & Pasir (terintrusi air laut) \\
\hline
\end{tabular}

TABEL IV: Hasil interpretasi litologi batuan bawah permukaan pada titik Sch-04. (Posisi titik sounding 109,2718 ${ }^{\circ}$ BT dan 7,6873 ${ }^{\circ}$ LS)

\begin{tabular}{lccl}
\hline $\begin{array}{l}\text { Lapisan } \\
\text { Batuan }\end{array}$ & $\begin{array}{c}\text { Resistivi- } \\
\text { tas }(\Omega \mathrm{m})\end{array}$ & $\begin{array}{c}\text { Kedalam- } \\
\text { an (meter) }\end{array}$ & $\begin{array}{l}\text { Interpretasi } \\
\text { Litologi }\end{array}$ \\
\hline Lapisan 1 & 90,40 & $0-1,35$ & Tanah permukaan (top soil) \\
Lapisan 2 & 114,30 & $1,35-4,28$ & $\begin{array}{l}\text { Perselingan pasir, lempung, } \\
\text { kerikil, dan kerakal }\end{array}$ \\
Lapisan 3 & 25,86 & $4,28-15,97$ & $\begin{array}{l}\text { Pasir besi berselingan dengan } \\
\text { lanau dan lempung }\end{array}$ \\
Lapisan 4 & 4,04 & $\begin{array}{c}\text { 15,97-37,98 } \\
\text { Pasir lempungan }\end{array}$ \\
Lapisan 5 & 0,83 & ¿37,98 & Pasir (terintrusi air laut) \\
\hline \hline
\end{tabular}

resistivitas dan log resistivitas yang terdiri atas lima lapis batuan yang diestimasi dari formasi alluvium. Berdasarkan nilai resistivitas yang diperoleh yang didukung informasi
TABEL V: Hasil interpretasi litologi batuan bawah permukaan pada titik Sch-05. (Posisi titik sounding $109,2718^{\circ}$ BT dan $7,6873^{\circ}$ LS

\begin{tabular}{|c|c|c|c|}
\hline $\begin{array}{l}\text { Lapisan } \\
\text { Batuan }\end{array}$ & $\begin{array}{l}\text { Resistivi- } \\
\operatorname{tas}(\Omega \mathrm{m})\end{array}$ & $\begin{array}{l}\text { Kedalam- } \\
\text { an (meter) }\end{array}$ & $\begin{array}{l}\text { Interpretasi } \\
\text { Litologi }\end{array}$ \\
\hline Lapisan 1 & 43,28 & $0-1,68$ & $\begin{array}{l}\text { Tanah permukaan (top soil) } \\
\text { berselingan dengan pasir besi }\end{array}$ \\
\hline Lapisan 2 & 116,99 & $1,68-2,60$ & $\begin{array}{l}\text { Perselingan pasir, lempung, } \\
\text { kerikil, dan kerakal }\end{array}$ \\
\hline Lapisan 3 & 25,55 & $2,60-8,39$ & $\begin{array}{l}\text { Pasir besi berselingan dengan } \\
\text { lanau dan lempung }\end{array}$ \\
\hline Lapisan 4 & 90,24 & $8,39-14,86$ & Pasir lempungan (dense) \\
\hline Lapisan 5 & 0,70 & $>14,86$ & Pasir (terintrusi air laut) \\
\hline
\end{tabular}

TABEL VI: Hasil interpretasi litologi batuan bawah permukaan pada titik Sch-06. (Posisi titik sounding $109,2718^{\circ}$ BT dan 7,6873 ${ }^{\circ}$ LS)

\begin{tabular}{|c|c|c|c|}
\hline $\begin{array}{l}\text { Lapisan } \\
\text { Batuan }\end{array}$ & $\begin{array}{l}\text { Resistivi- } \\
\operatorname{tas}(\Omega \mathrm{m})\end{array}$ & $\begin{array}{l}\text { Kedalam- } \\
\text { an (meter) }\end{array}$ & $\begin{array}{l}\text { Interpretasi } \\
\text { Litologi }\end{array}$ \\
\hline Lapisan 1 & 89,22 & $0-3,85$ & $\begin{array}{l}\text { Tanah permukaan (top soil) } \\
\text { berselingan dengan pasir besi }\end{array}$ \\
\hline Lapisan 2 & 46,96 & $3,85-12,26$ & $\begin{array}{l}\text { Pasir besi berselingan dengan } \\
\text { lanau dan lempung }\end{array}$ \\
\hline Lapisan 3 & 10,30 & $12,26-28,47$ & Pasir lempungan \\
\hline Lapisan 4 & 5,75 & $28,47-80,39$ & \\
\hline Lapisan 5 & 4,66 & $>80,39$ & Pasir \\
\hline
\end{tabular}

geologi daerah penelitian, dilakukan interpretasi litologi atau penafsiran jenis batuan terhadap masing-masing lapisan batuan bawah permukaan. Hasil pemodelan data resistivitas 
dan hasil interpretasi litologinya dapat dilihat sebagaimana Tabel I. Selanjutnya hasil pemodelan resistivitas batuan bawah permukaan pada titik-titik sounding Sch-02 hingga Sch-06 ditunjukkan pada Gambar 7 hingga Gambar 11, serta hasil interpretasi litologinya ditunjukkan pada Tabel II Tabel VI. Posisi geografis yang terdiri atas lintang dan bujur untuk masing-masing titik sounding juga ditunjukkan pada tabel-tabel tersebut.

Tabel I - Tabel VI menunjukkan bahwa endapan pasir besi ditemukan di seluruh titiksounding dengan nilai resistivitas berkisar 12,24-46,96 $\Omega \mathrm{m}$ dan kedalaman berkisar 2,39-27,81 meter, dalam bentuk perselingan dengan lanau dan lempung. Pada titik Sch-03 diinterpretasi terdapat endapan pasir, lanau, lempung, kerikil yang berselingan dengan bijih besi dengan nilai resistivitas 72,82 $\Omega \mathrm{m}$ serta kedalaman 3,13-9,46 meter. Berdasarkan pengamatan langsung di lokasi penelitian, pasir besi juga ditemukan berselingan dengan tanah permukaan (top soil). Menurut penelitian yang telah dilakukan oleh Hikmatyar (2016), pasir besi dikawasan pesisir pantai Cilacap termasuk Kecamatan Nusawungu tidak tersebar merata [14]. Berdasarkan hasil analisis kimia sampel tanah permukaan yang diambil menggunakan bortangan di dekat garis pantai pada kedalaman 0,8-1,6 meter diperoleh kandungan besi $(\mathrm{Fe})$ sebesar 9,56\% yang berada pada kedalaman 0,8-1,1 meter [14].

Selanjutnya hasil interpretasi ini dapat dibuat peta potensi pasir/bijih besi yang dikorelasikan dengan peta kontur anomali magnetik lokal daerah penelitian sebagaimana Gambar 7. Gambar ini menunjukkan bahwa potensi bijih besi di kawasan pesisir barat Kecamatan Nusawungu Kabupaten Cilacap diperkirakan cukup besar sehingga prospek untuk dieksploitasi khususnya untuk memenuhi kebutuhan pasir besi bagi industri nasional. Namun demikian formasi alluvium yang kaya akan bijih besi mempunyai peran penting mempertahankan kawasan pantai dari ancaman abrasi dan intrusi air laut [15]. Oleh karena itu jika eksploitasi pasir besi dilakukan, kelestarian lingkungan pesisir harus terjaga dengan cara tidak merusak lapisan alluvium sebagai zona penyangga pada saat eksploitasi atau penambangan dilakukan.

\section{SIMPULAN}

Survei geolistrik resistivitas untuk menginvestigasi sebaran dan potensi pasir besi di pesisir barat Kecamatan Nusawungu Kabupaten Cilacap telah dilakukan pada bulan Mei-Juli 2017. Pengukuran data resistivitas dilakukan di enam titik lokasi yang diperkirakan prospek mengandung pasir atau bijih besi berdasarkan peta anomali magnetik lokal daerah penelitian. Hasil pemodelan dan interpretasi data resistivitas satu dimensi yang diperoleh menunjukkan keberadaan endapan pasir besi yang berselingan dengan lanau dan lempung dari formasi alluvium di hampir seluruh titik lokasi. Endapan pasir besi tersebut diperkirakan terletak pada kedalaman berkisar 2,39-27,81 meter. Selain itu pada beberapa titik lokasi, bijih besi juga ditemukan dalam bentuk perselingan dengan batuan pasir, lanau, lempung, kerikil, dan kerakal; serta perselingan dengan tanah permukaan (top soil).

\section{Ucapan Terima Kasih}

Terima kasih yang tulus penulis sampaikan kepada Direktur Jenderal Pendidikan Tinggi Kementerian Riset, Teknologi, dan Pendidikan Tinggi Republik Indonesia, Rektor Universitas Jenderal Soedirman Purwokerto, Ketua Lembaga Penelitian dan Pengabdian Masyarakat UNSOED atas dana yang telah disediakan. Terima kasih disampaikan kepada Kepala Laboratorium Elektronika, Instrumentasi, dan Geofisika UNSOED atas peralatan yang disediakan. Terima kasih juga disampaikan untuk seluruh crew peneliti yang terdiri atas dosen dan mahasiswa yang telah bekerja keras, bahu-membahu, dan semangat dalam melaksanakan akuisisi data di lapangan.
[1] R. Burhani, "Cadangan Pasir Besi di Cilacap Menurun", www.antaranews.com, 2017.

[2] D. Sugandi, "Tambang Pasir Besi Cilacap; Alih Fungsi Sawah Menjadi Tambang di Cilacap", http://denisugandi.com, 2014.

[3] Pikiran Rakyat (online), Pasir Besi di Cilacap Tinggal 600 Ribu Ton, http://www.pikiran-rakyat.com /nasional/2012/07/21/196775/pasir-besi-di-cilacap-tinggal600-ribu-ton, 2012.

[4] Sehah, $d k k$., "Pengembangan Sumber Daya Perdesaan dan Kearifan Lokal Berkelanjutan VII", Seminar Nasional dan Call for Papers, LPPM UNSOED Purwokerto, 17 -18, November 2017

[5] Sehah, et al. , "Exploration of Iron Sand at The Eastern Coast Area of Binangun in Cilacap Regency Using Magnetic Survey", Indonesian Journal of Applied Physics (IJAP), vol. 07, no. 2, pp. 71-81, 2017.

[6] F.P. Omowumi, "Application of Electrical Resistivity in Buildings Foundation Investigation in Ibese Southwestern Nigeria",
Asia Pasific Journal of Energy and Environment (APJEE), vol. 1, no. 2, pp. 95-107, 2014.

[7] W.M. Telford, L.P. Gedaart, R.E. Sheriff, "Applied Geophysics", Cambridge, 1990.

[8] R. Saad, et.al., "Groundwater Detection in Alluvium Using 2-D Electrical Resistivity Tomography (ERT)", Electronic Journal of Geotechnical Engineering (EJGE), vol. 17, pp. 2973-2979, 2012.

[9] Sehah dan S. A. Raharjo, Jurnal Penelitian Fisika dan Aplikasinya (JPFA), vol. 07, no. 2, hal. 79-88, 2017.

[10] E. Nkitnam, and E. Abraham, "Schumberger Resistivity Sounding for Groundwater Exploration: A Case Study of Kajuru Area of Northern Nigerian Basement Complex", Global Journal of Engineering Science and Research Management, vol. 2, no. 10, pp. 6-14, 2015.

[11] Sehah dan A.N. Aziz, "Pendugaan Kedalaman Air Tanah menggunakan Metode Geolistrik Konfigurasi Schlumberger di desa Bojongsari, Kecamatan Alian, Kabupaten Kebumen", Jurnal 
Neutrino, vol. 8, no. 2, pp. 41-49, 2016.

[12] Asikin, $d k k$., "Peta Geologi Lembar Banyumas, Jawa", P3G Bandung, 1992.

[13] D.Z. Herman, "Kolokium Hasil Lapangan-DIM", PSDGESDM Bandung, 2005.

[14] M.S. Hikmatyar, "Geologi dan Karakteristik Pantai serta Kai- tannya dengan Keterdapatan Pasir Besi di Pantai Selatan Cilacap Jawa Tengah”, Skripsi S-1, Fakultas Teknik, Universitas Jenderal Soedirman Purwokerto, 2016.

[15] Sehah, $d k k$., Indonesian Journal of Applied Physics, vol. 06, no. 2, pp. 97-106, 2016 